\title{
Occupational exposure to water based paint and symptoms from the skin and eyes
}

\author{
G Wieslander, D Norbäck, C Edling
}

\begin{abstract}
Water based paints contain organic solvents and many additives, such as biocides, surfactants, pigments, binders, amines, and monomers. The chemical complexity may introduce new potential health hazards to house painters, in particular irritative and allergic disorders. This study was performed to compare how house painters experience work with water based paints or solvent based paints, and to evaluate whether exposure to water based paints increases mucous membrane and dermal symptoms among house painters. 255 male house painters aged 20 to 65 were invited to participate in the study. Controls were two industrial populations, in total 302 men, without exposure to water based paints. Self administered questionnaires were used to assess the painter's experiences of working with different types of paints and the occurrence of symptoms in the exposed and unexposed groups. Hygiene measurements were performed during normal working days when only water based paints and no solvent based paints were used. The painters were exposed to low concentrations of dust, metals, ammonia, formaldehyde, and volatile organic compounds. The work environment was considered better when working with water based paints than with solvent based paints. There were more complaints of frequent urination when working with water based paint. Taste or olfactory disturbances were less common. General as well as work related eye and skin irritation was more common among the exposed workers. For other symptoms no significant differences were found. The study indicates that the introduction of water based paints has improved the work environment for house painters. Water based paints cause less discomfort and airway irritation than the earlier solvent based paints. Adverse general health effects seem low. Some of the painters may have dermal symptoms caused by the components in water based paints.
\end{abstract}

(Occup Environ Med 1994;51:181-186)

The chemistry of paints has changed over time, and so have the potential health hazards for house painters. At the beginning of the 20th century, arsenic was often used as a pigment in paints and wall paper, and caused systemic poisoning. ${ }^{1}$ Before the second world war, turpentine was used as a solvent in building paints, and both kidney dysfunction ${ }^{2}$ and contact allergy ${ }^{1}$ related to exposure to turpentine was reported. Later, turpentine was replaced by organic solvents such as white spirit, butanol, methyl ethyl ketone (MEK), and ethyl acetate or butyl acetate. ${ }^{3}$ These compounds are more volatile than turpentine, and consequently resulted in a high exposure to organic solvents both in the paint industry and among house painters. Initially, this exposure to solvents was considered to have no major adverse effects. During the past few decades, however, several epidemiological studies have shown that occupational exposure to organic solvents may cause acute and chronic dysfunction of the peripheral and central nervous system. ${ }^{4}$ Therefore, the paint industry started to develop new types of paints, with considerably smaller amounts of organic solvents. These new so called water based paints contain an emulsion of pigments and polymers in water with small amounts of various chemicals such as volatile organic compounds (organic solvents) and biocides.

In Sweden the use of solvent based paint for professional indoor painting has gradually decreased, from $40 \%$ in 1970 to $10 \%$ in 1985. The Swedish painters union in 1987 urged their members to further minimise the use of solvent based paints and use water based paints when possible. In 1992 the use of solvent based paints among house painters in Sweden was only $4 \%$ of the total paint consumption.

One advantage of water based paints is that they reduce the exposure to organic solvents. The chemistry of water based paints is, however, more diverse and complex than that of solvent based paints. Water based paints contain many additives, such as biocides, surfactants, pigments, binders, amines, monomers, and solvents. ${ }^{56}$ This chemical complexity may introduce new potential health hazards to house painters. Swedish painters have reported skin irritation, frequent urination and stomach problems when using water based paints. Ulfvarson et al recently published a study in which they found a temporary increase in urine excretion and a decrease in urine density as well as a small increase in mean red cell volume and a decreased forced expiratory volume in one second $\left(\mathrm{FEV}_{1}\right)$ among painters exposed to experimental water based paints. ${ }^{7}$ In another study on 
painters who worked with water based paints, the authors reported a possible effect on the kidneys, measured as an increased excretion of albumin in the urine. ${ }^{8}$ To elucidate further the health consequences of exposure to water based paints we have started field studies among active house painters. The interest is focused on the exposure situation, symptoms, lung and kidney function, and skin allergy. This is the first part of the health related studies.

Our study had two aims. The first was to evaluate how the painters experienced work with solvent based and water based paints, regarding the general work environment, malodour, and some work related symptoms. The second was to evaluate whether house painters exposed to water based paints had more mucous membrane and dermal symptoms than workers without such exposure.

\section{Material and methods}

SUBJECTS

The study took place in the counties of Gävleborg and Dalecarlia in mid-Sweden. During March 1989, all major (>20 employees) painting companies in the region were identified with the help of the Regional Construction Industry's Organisation for Working Environment, Safety, and Health. In total, five privately owned companies, and one trade union owned company with more than 20 employees were identified. To increase the homogeneity of the exposed population and the comparability with the controls, the study was restricted to include only male house painters aged 20 to 65 employed by the five privately owned companies. All 255 painters in this age group were invited to participate in the study. As controls we used two industrial populations available from two of our other studies..$^{10}$ One group comprised 109 male dairy workers (age 20 to 65) employed in a large privately owned dairy in the county of Dalecarlia. The other control group included 193 male packers (age 20 to 65) employed at the paper pulp stores in three private pulp industries in the two county regions. None of the controls was occupationally exposed to organic solvents or water based paints. Also, workplace monitoring among the packers showed that the exposure to dust $\left(0.2 \mathrm{mg} / \mathrm{m}^{3}\right)$ and volatile organic compounds $\left(0.5 \mathrm{mg} / \mathrm{m}^{3}\right)$ was very low. ${ }^{10}$

\section{ASSESSMENT OF EXPOSURE}

We collected information from the supervisors of the different companies during April 1989 about the use of different types of paint. Also, each painter was asked to estimate the average number of hours he worked with water based and solvent based paint.

Monitoring of the workplace was performed on 12 painters from different companies during normal workdays when only water based paints and no solvent based paints were used. We measured dust, metals, ammonia, formaldehyde, and volatile organic compounds. The painters did normal work tasks, such as painting, removal of old wall paper, manual sanding of walls with abrasive paper, manual filling, and sizing of wet room wall papers. No spray filling work was done during the measurements. Six full days were measured during work in new buildings under construction and six full days during work in old buildings. Also, peak exposure to ammonia, formaldehyde, and volatile organic compounds were measured by short term sampling. All measurements of exposure were carried out by personal sampling in the breathing zone of the painter.

The total dust concentration was measured by gravimetric analysis of dust collected on $28 \mathrm{~mm}$ cellulose acetate filters with a pore size of $0.8 \mu \mathrm{m} .{ }^{11}$ The organic dust concentration was measured as the weight difference before and after low temperature ashing of the total dust samples collected on the filters. The concentrations of metals in the dust were measured by a quantitative $x$ ray fluorescence technique.

The long term exposure to ammonia was determined by diffusion sampling with a direct reading tube (Dräger diffusion tube ammonia 20/a-D). The peak exposure to ammonia was measured by direct reading detector tubes (Dräger 2/a). Both types of tubes are based on a colour reaction between ammonia and bromophenol blue. Besides ammonia other basic volatile compounds, such as amines, would also be detected, but with different sensitivity.

Long term exposure to formaldehyde was measured by diffusion sampling, with chemosorption on 2,4-dinitrophenyl hydrazine $(2,4-$ DNF) coated glass fibre filters. ${ }^{12}$ Peak exposure to formaldehyde was measured with glass fibre filters impregnated with 2,4-DNF, with the air rate at $1 \mathrm{l} / \mathrm{min}$ for 15 minutes. ${ }^{13}$ The filters were analysed by liquid chromatography.

Volatile organic compounds were sampled on charcoal sorbent tubes (SKC 226-01), with an air sampling rate of $50-250 \mathrm{ml} / \mathrm{min}$. The charcoal tubes were desorbed with $1 \mathrm{ml}$ of carbon disulphide before analysis, which was performed within two weeks of the sampling day on a gas chromatograph (Hewlet Packard 5880) equipped with a flame ionisation detector and packed columns. Sixteen common solvents were identified and quantified with the external standard technique, by comparing the retention times on two different columns. When quantifying low boiling uncalibrated hydrocarbons (C3-C12) the response factor of $n$-decane was used; high boiling unknown hydrocarbons $(>\mathrm{C} 12)$ used the response factor of a mixture of high boiling hydrocarbons (dodecylbenzenes). The total concentration of the identified and unidentified hydrocarbons in air was calculated and expressed as $\mathrm{mg} / \mathrm{m}^{3}$

To identify unknown compounds, and to be able to detect a wider range of compounds, gas chromatography and mass spectrometric analyses were also performed on air samples drawn through sorbents other than charcoal (Teenax, XAD-2 and XAD-7). 
Teenax was desorbed thermally and the other types of sorbents were desorbed by $2 \mathrm{ml}$ of methylene chloride mixed with $5 \%$ of methanol.

\section{ASSESSMENT OF THE EXPERIENCE OF DIFFERENT TYPES OF PAINTS}

To evaluate how the painters experienced work with solvent based paints and water based paints they were asked to answer a set of questions on the general work environment, degree of malodour, and some work related symptoms. Two self administered questionnaires were mailed to the subject's home address in April 1989. One questionnaire inquired about the painter's experiences of working with different types of paints, the other about symptoms. The questions asked in the first questionnaire were: How do you consider the work environment when working with water based paints or solvent based paints (two questions)? The answer alternatives were: very good, good, bad, and very bad. What is the degree of malodour from the water based paints or solvent based paints (two questions)? Do you experience any airway irritation when working with water based paints or solvent based paints (two questions)? The alternative answers to these two questions were: none, slight, moderate, strong. Finally, there was an open ended question: Do you have any other symptoms or complaints that you consider to be due to your work with water based paints or solvent based paints.

\section{ASSESSMENT OF SYMPTOMS}

The occurrences of mucous membrane and dermal symptoms in the exposed and unexposed groups were recorded by a questionnaire we used in a previous study regarding the sick building syndrome. ${ }^{14}$ The questionnaire inquired about smoking habits, atopy (asthma, hay fever, or a history of eczema in childhood), hyperreactivity, and sick leave. It also contained questions with yes or no answers on 12 questions on symptoms from mucous membranes, eyes, and skin. Furthermore, it included eight questions on work related mucous membrane and dermal irritation. All questions covered the prevalence during the previous two years. No information on the severity of the symptoms was gathered.

Also, work stress and work satisfaction

Table 1 Selected demographic data for exposed house painters and two unexposed control groups

\begin{tabular}{lllll}
\hline Characteristics & $\begin{array}{l}\text { Painters } \\
\%(n=236)\end{array}$ & $\begin{array}{l}\text { Dairy workers } \\
\%(n=102)\end{array}$ & $\begin{array}{l}\text { Packers } \\
\%(n=137)\end{array}$ & $\begin{array}{l}\text { Two tailed } \\
p \text { value }\end{array}$ \\
\hline $\begin{array}{l}\text { Current tobacco smokers } \\
\text { Subjects with signs }\end{array}$ & 20 & 21 & 29 & NS \\
$\begin{array}{l}\text { of atopy } \\
\text { Non-specific airway }\end{array}$ & 19 & 16 & 18 & NS \\
$\begin{array}{l}\text { hyperreactivity† } \\
\text { Frequent consumption of } \\
\text { medicine }\end{array}$ & 23 & 29 & 20 & NS \\
\hline
\end{tabular}

* Subjects with a history of asthma, hay fever, or eczema in childhood.

†Easily irritated respiratory tract during exposure to non-specific irritants (tobacco smoke, exhaust gases, organic solvents).

$\ddagger$ Calculated by $x^{2}$ test for $2 \times 2$ contingency tables. were measured in both groups by analogue rating scales. ${ }^{14}$

ASSESSMENT OF SELECTION EFFECTS

Information about workers who left the six companies during the two year period preceding the study ( 1 January 1987 to 15 April 1989) was collected from the administration offices of the companies by checking their registers. These included information on migration to other regions, change of employer, retirement, work related diseases approved by the national social insurance service, other diseases, and deaths.

\section{STATISTICAL METHODS}

Differences in mean values of work stress and work satisfaction were calculated by Student's $t$ test. As most variables were not normally distributed we used non-parametric tests. The Mann-Whitney $U$ test was used to test differences in exposures when working in new $v$ old buildings. Paired comparisons of the experience of different types of paints were made by Wilcoxon matched pairs signed rank test. Differences in proportions were calculated by the two tailed $\chi^{2}$ test or when there were small numbers, by Fisher's exact test for $2 \times 2$ contingency tables. Geometric means and geometric SDs, as proposed by Saltzman, ${ }^{15}$ were used in calculating the average exposure to different compounds. The level of significance was set at $5 \%$ in all statistical analyses. For each symptom, an odds ratio (OR) with a $95 \%$ confidence interval (95\% CI) was calculated. The MantelHaenszel procedure was used to calculate the total ORs and stratification was used to calculate ORs for multiple categories.

\section{Results}

In the exposed group, 236 of 255 painters $(93 \%)$ answered the questionnaires. The response rate among dairy workers was $94 \%$ (102 of 109) and among storage workers $71 \%$ (137 of 193). The mean age was 36 for the painters and 37 in both control groups. Most of the painters had a previous exposure of more than 10 years to solvent based paint, as they had worked, on average, for 18 years as house painters. The prevalence of smokers, persons with atopy, and non-specific hyperreactivity, as well as regular use of medicine was about the same in the exposed and the two control groups (table 1). The prevalence of both general and work related symptoms was not significantly different between the two control groups. Therefore, the two groups were combined in the analyses.

The use of paint (ceiling paint, wall paint, paints for window frames) per person, measured in litres, was of the same magnitude in the different companies.

For technical reasons only two measurements of volatile organic compounds performed in old buildings could be analysed. The hygiene measurements (table 2) showed that the painters were exposed to low concentrations of a complex mixture of various types 
Table 2 Average eight hour exposure ( $\mathrm{mg} / \mathrm{m}^{3}$ ) of 12 painters to dust, metals, formaldehyde, ammonia, and volatile organic compounds (VOC) in various brands of water based paints

\begin{tabular}{lllllc}
\hline Type of exposure & $\begin{array}{l}\text { Arithmetic } \\
\text { mean }\end{array}$ & $\begin{array}{l}\text { Geometric } \\
\text { mean }\end{array}$ & $\begin{array}{l}\text { Geometric } \\
\text { SD }\end{array}$ & $\begin{array}{l}\text { Range } \\
\text { (min-max) }\end{array}$ & $\begin{array}{l}\text { Swedish } \\
P E L^{\star}\end{array}$ \\
\hline Total dust & $4 \cdot 1$ & 2.5 & 2.9 & $0.4-14$ & 10 \\
Organic dust & 1.4 & 0.8 & 3.6 & $0.1-3.7$ & 5 \\
Calcium & 0.3 & 0.2 & 2.5 & $0.1-0.9$ & $2 \dagger$ \\
Iron & 0.02 & 0.02 & 2.1 & $0.004-0.05$ & 3.5 \\
Titanium & 0.01 & 0.01 & 3.3 & $<0.001-0.05$ & $5 \dagger$ \\
Zinc & 0.02 & 0.004 & 7.1 & $<0.001-0.08$ & $5 \dagger$ \\
Lead & 0.001 & 0.001 & 2.2 & $<0.001-0.003$ & 0.1 \\
Cobalt & 0.001 & 0.001 & 1.7 & $<0.001-0.003$ & 0.05 \\
Formaldehyde & 0.05 & 0.04 & 1.9 & $<0.03-0.1$ & 0.6 \\
Ammonia & 0.9 & 0.7 & 3.6 & $<0.4-3.9$ & 18 \\
VOC $\neq$ & 2.1 & 1.6 & 2.1 & $0.7-4.9$ & - \\
\hline
\end{tabular}

^Current Swedish occupational permissible exposure limit (PEL) for eight hour time weighted average exposure.

†PEL value for metal oxides.

¥Volatile organic compounds; measurements available from eight subjects.

Table 3 Paired comparison of different aspects on water based paints and solvent based paints, as judged by the house painters $(n=236)$

\begin{tabular}{|c|c|c|c|}
\hline Aspect & $\begin{array}{l}\text { Water based } \\
\text { paint better } \\
(\%)\end{array}$ & $\begin{array}{l}\text { Both types } \\
\text { equal } \\
(\%)\end{array}$ & $\begin{array}{l}\text { Solvent based } \\
\text { paint better } \\
(\%)\end{array}$ \\
\hline \multirow{2}{*}{$\begin{array}{l}\text { Malodour } \\
\text { Airway irritation } \\
\text { General work } \\
\text { environment }\end{array}$} & $\begin{array}{l}92 \\
56\end{array}$ & $\begin{array}{r}8 \\
41\end{array}$ & $\begin{array}{l}0 \cdot 4^{\star \star \star \star} \\
3^{\star \star \star}\end{array}$ \\
\hline & 49 & 50 & $1^{\star \star \star \star}$ \\
\hline
\end{tabular}

${ }^{\star \star \star} \mathrm{p}<0.001$ by Wilcoxon matched pairs signed rank test

Table 4 The percentage of painters who reported urinary, gastrointestinal, and taste or olfactory disturbances in relation to use of water based and solvent based paints $(n=236)$

\begin{tabular}{lll}
\hline & $\begin{array}{l}\text { At work } \\
\text { with water } \\
\text { based } \\
\text { paint (\%) }\end{array}$ & $\begin{array}{l}\text { At work } \\
\text { with solvent } \\
\text { based } \\
\text { paint (\%) }\end{array}$ \\
\hline Type of disturbance & 4 & $0^{\star \star}$ \\
\hline Frequent urination & 4 & 4 \\
Gastrointestinal problems & 0.4 & $3^{\star}$ \\
\hline Taste or olfactory disturbance & 0.4
\end{tabular}

${ }^{\star} \mathrm{p}<0.05 ;{ }^{\star \star} \mathrm{p}<0.01$ both by Fisher's exact test.

Table 5 Symptom prevalence during previous two years, and ORs with $95 \%$ CIs in exposed house painters and non-exposed controls

\begin{tabular}{|c|c|c|c|}
\hline Characteristics & $\begin{array}{l}\text { Painters } \\
\%(n=236)\end{array}$ & $\begin{array}{l}\text { Controls } \\
\%(n=239)\end{array}$ & OR $(95 \% C I)$ \\
\hline $\begin{array}{l}\text { Eye irritation } \\
\text { Swollen eyelids }\end{array}$ & $\begin{array}{r}22 \\
6\end{array}$ & $\begin{array}{r}15 \\
4\end{array}$ & $\begin{array}{l}1.7(1.03-2.7) \\
1.4(0.6-3.3)\end{array}$ \\
\hline $\begin{array}{l}\text { Nasal catarrh } \\
\text { Blocked up nose } \\
\text { Dryness in the throat } \\
\text { Sore throat } \\
\text { Irritative cough }\end{array}$ & $\begin{array}{r}18 \\
22 \\
11 \\
7 \\
11\end{array}$ & $\begin{array}{r}21 \\
21 \\
14 \\
8 \\
8\end{array}$ & $\begin{array}{l}0.8(0.5-1.3) \\
1.1(0.7-1.6) \\
0.8(0.4-1.3) \\
0.8(0.4-1.7) \\
1.5(0.8-2.7)\end{array}$ \\
\hline $\begin{array}{l}\text { Facial itch } \\
\text { Facial rash } \\
\text { Itching on the hands } \\
\text { Rashes on the hands } \\
\text { Eczema }\end{array}$ & $\begin{array}{r}8 \\
9 \\
17 \\
14 \\
12\end{array}$ & $\begin{array}{r}6 \\
7 \\
10 \\
12 \\
11\end{array}$ & $\begin{array}{l}1.3(0.7-2 \cdot 7) \\
1.3(0.7-2.5) \\
1.9(1.1-3.3) \\
1.2(0.7-2.0) \\
1.1(0.6-1.9)\end{array}$ \\
\hline
\end{tabular}

Table 6 Two year prevalence of work related symptoms (>once a week), and ORs with 95\% CIs in exposed house painters and non-exposed controls

\begin{tabular}{llll}
\hline Characteristics & $\begin{array}{l}\text { Patients } \\
\% \\
(n=236)\end{array}$ & $\begin{array}{l}\text { Controls } \\
\% \\
(n=239)\end{array}$ & OR $(95 \% C I)$ \\
\hline Eye irritation & 8 & 4 & $2 \cdot 3(1 \cdot 03-5 \cdot 1)$ \\
Blocked up nose & 11 & 12 & $0.9(0 \cdot 5-1 \cdot 5)$ \\
Dryness in the throat & 11 & 12 & $0 \cdot 9(0 \cdot 5-1 \cdot 6)$ \\
Sore throat & 2 & 2 & $1 \cdot 0(0 \cdot 3-4 \cdot 1)$ \\
Irritative cough & 5 & 5 & $1 \cdot 0(0 \cdot 4-2 \cdot 4)$ \\
Cough with sputum & 7 & 5 & $1 \cdot 5(0 \cdot 7-3.3)$ \\
Facial itch & 2 & 4 & $0 \cdot 4(0 \cdot 2-1 \cdot 4)$ \\
Itching on the hands & 4 & 3 & $1 \cdot 3(0 \cdot 5-3 \cdot 3)$ \\
\hline
\end{tabular}

of volatile organic compounds, metals, formaldehyde, and ammonia. The average exposure to organic and inorganic dust was considerably lower than the present occupational exposure limit values in Sweden, although the Swedish permissible exposure to total dust was exceeded on a few occasions. The dust exposure emanated from work tasks other than painting, such as removal of old wallpaper, manual filling and sanding of walls. A significantly higher exposure to organic dust could be shown, in renovation work in old buildings $\left(2 \cdot 1 \mathrm{mg} / \mathrm{m}^{3}\right)$ than in new buildings, $\left(0.7 \mathrm{mg} / \mathrm{m}^{3}\right)$. There was a non-significant tendency (Mann-Whitney $U$ test) to a higher average exposure to ammonia during work days in new $\left(1.4 \mathrm{mg} / \mathrm{m}^{3}\right)$ compared with old buildings $\left(0.4 \mathrm{mg} / \mathrm{m}^{3}\right)$. The highest peak concentrations of ammonia $\left(13 \mathrm{mg} / \mathrm{m}^{3}\right)$ and formaldehyde $\left(0.14 \mathrm{mg} / \mathrm{m}^{3}\right)$ were measured when the painters used special wet room paints in bathrooms in newly constructed apartments.

Some organic solvents typical of solvent based paints, such as iso-butanole, toluene, xylene, trimethyl benzene, $n$-nonane, $n$ decane, and $n$-undecane are also emitted from water based paints, but in concentrations less than $1 \%$ of those from solvent based paints. Also, water based paints were found to emit different polar compounds, such as glycols and glycol ethers. Detailed results on the exposure to various types of volatile organic compounds during work with different types of water based paints will be published separately.

The painters judged the general work environment to be better when they used water based paints compared with solvent based paints (table 3 ). They also reported less malodour and airway irritation when they painted with water based paints (table 3 ). In the open ended questions most workers complained of ergonomic problems regardless of type of paint used. Concerning problems related to chemical exposure, the painters complained about taste or olfactory disturbances, gastrointestinal disorders, and urination problems (table 4). They noticed less taste or olfactory disturbances when working with water based paints. They needed to urinate more often when they used water based paints whereas the complaints of gastrointestinal disorders were of the same magnitude regardless of type of exposure. The differences were all statistically significant.

Nine out of the 12 different symptoms were more common during the previous two years among the painters than the controls (table 5). Eye irritation (OR = 1.7) and itching on the hands $(O R=1.9)$ had the highest prevalence. Nasal catarrh, dryness in the throat, and sore throat were less common among the painters than the controls.

The work related symptoms eye irritation $(O R=2 \cdot 3)$, cough with sputum $(O R=1 \cdot 5)$, and itchy hands $(O R=1 \cdot 3)$, were all more common (more than once a week) among painters than controls (table 6). For work related itching of the hands the $O R$ was 
Table 7 Odds ratios correlated with average number of hours working with solvent based paints among 52 painters with and 182 painters without eye irritation

\begin{tabular}{lccc}
\hline & \multicolumn{2}{l}{ Eye irritation } & \\
\cline { 2 - 4 } Work hours with solvent based paint & With & Without & OR $(95 \%$ CI) \\
\hline <1 hour/week & 17 & 87 & $1 \cdot 0-1 \cdot 5-3 \cdot 4)$ \\
1-5 hours/week & 24 & 73 & $1 \cdot 7(0 \cdot 8-3 \cdot 4)$ \\
$6-20$ hours/week & 5 & 16 & $1 \cdot 6(0 \cdot 5-4 \cdot 9)$ \\
$>20$ hours/week & 6 & 6 & $5 \cdot 1(1 \cdot 6-16 \cdot 3)$ \\
Mantel-Haenszel estimate & 52 & $182^{\star}$ & $2 \cdot 0(1 \cdot 2-3 \cdot 4)$ \\
\hline
\end{tabular}

^Incomplete answer from two painters.

increased to $3 \cdot 6(95 \% \mathrm{CI} 2 \cdot 0-6 \cdot 2)$ if defined as more than once a month.

To investigate the finding of work related eye and skin symptoms further, a doseresponse analysis was performed. The average number of work hours with water based and solvent based paint was used as the exposure variable. These analyses showed that eye irritation was related to the number of hours the painter worked with solvent based paints (table 7). No dose-response relation within the exposed group of painters could be found for water based paints and eye irritation, or work related skin irritation.

The painters reported a higher degree of work satisfaction and more work stress than the controls. These differences were significant (Student's $t$ test).

During the two year period (1987-88) preceding the study, 75 patients had left their employment. Most of them (60) left because of regional migration or change of employer in the same region. Five painters had retired and two had died. Eight painters had left because of what they judged to be work related problems, although the diseases were not approved by the National Social Insurance Service. The disorders were four cases of neck and shoulder problems, two cases of eczema, and two cases of asthma.

\section{Discussion}

This study showed that the change from solvent based paints to water based paints has improved the work environment for house painters. They are less exposed to solvents and have fewer complaints. Some irritative symptoms still exist and need further evaluation. Exposure measurements show generally low concentrations of solvents in the air. Total dust exposures can be temporarily high and peaks of formaldehyde and ammonia still occur at an unacceptable frequency. For example, poor ventilation during bathroom painting might cause acute irritative symptoms and malodour due to ammonia and formaldehyde exposure.

A cross sectional study design may have certain drawbacks due to the selection processes, work organisation, and the number of available employees, thus limiting the validity of the study. The most obvious drawback is a possible underestimation of a true effect because people with pronounced symptoms or effects have left their jobs, (a health based selection of workers). To estimate such effects we gathered information on those painters who left the five companies during the two years preceding the study. A few of the painters had left because of possible work related diseases such as neck and shoulder problems, eczema, or asthma. Most painters left their employment because of reasons other than health.

Selection bias can occur both from incorrect study design and a low response rate. In this study both the exposed painters and one of the control groups (dairy workers) participated to a high degree and the loss of individuals was small, $7 \%$ and $6 \%$. In the other control group (storage workers) the nonparticipation rate was higher $(29 \%)$, and thus a selection bias could occur. As the prevalence of symptoms was similar in the two non-exposed groups, it is not likely that such selection bias had any major influence on the results of this study. To minimise regional differences between exposed and control groups we chose two different control groups within the two county region. This also allowed us to get an acceptable number of controls to include in the study.

Response bias due to awareness of exposure may influence the result and may cause a systematic bias in the reporting of symptoms in the exposed group. In our study the prevalence of most symptoms did not differ significantly between exposed and unexposed workers. The only significant differences were in eye irritation and skin itching. Work satisfaction as well as work stress could influence how a worker responds to questions about work related symptoms. Work stress might increase the possibility of over reporting, whereas work satisfaction could lead to an under reporting of symptoms. The painters reported a higher degree of work satisfaction and a higher degree of work stress than the controls and this might balance the possibility of over or under-reporting of symptoms.

Thus we do not think that the result of our study is biased by selection or response. The cross sectional design of the study could, however, underestimate the true effect of the exposure, particularly for eczema and asthma.

The painters' attitude toward water based paints was generally positive, and most painters considered water based paints to cause less airway irritation and less malodour than the earlier solvent based paints. The reports of the painters correspond to the hygiene measurements during work with water based paints. The eight hour exposure to total volatile organic solvents was very low $\left(0 \cdot 7-4.9 \mathrm{mg} / \mathrm{m}^{3}\right)$.

Besides exposure to volatile organic solvents the painters were exposed to ammonia, formaldehyde, metals, organic, and inorganic dust. The time weighted average exposures to ammonia, formaldehyde, and measured metals were less than $10 \%$ of the Swedish permissible exposure limits (PELs). The total dust, however, was higher and sometimes exceeded the Swedish PEL of $10 \mathrm{mg} / \mathrm{m}^{3}$. Hansen et al made a toxicological evaluation of common Danish water based paints. ${ }^{5}$ They recommended that substances like formaldehyde and turpentine should be avoided 
because of risks of irritation or skin allergy. In our study we found that during paint work in bathrooms where the general ventilation was poor and special wet room paint was used some painters complained about malodour. Such situations were associated with the highest concentrations of formaldehyde and ammonia.

Our finding of a perceived increased frequency of urination while working with water based paints is in accordance with the report of Ulfvarson et al. ${ }^{7}$ They found an increase in urine excretion and a decrease in urine density among workers who were experimentally exposed to different water based paints. The authors suggested that exposure to benzisothiazolinone was the cause of these effects.

The exposed painters had significantly more work related eye irritation. The eye irritation was most common in a subgroup of painters partly working with solvent based paints and clearly related to the number of hours the painters worked with these paints. We have not found any other human study that reports on the effect of water based paints on the skin or eyes. In one experimental animal study, however, the sensory irritation of the trigeminal nerve was studied for different types of Danish building materials. ${ }^{16}$ In that study a significant irritative effect was found for an acid cured paint, but not for the tested latex type of water based paints. Eye irritation because of exposure to organic solvents has been reported and verified by measurements of tear film stability. ${ }^{17}$ In an exposure chamber study even a moderate exposure to $n$-decane $\left(58 \mathrm{mg} / \mathrm{m}^{3}\right.$ over six hours) resulted in a decreased tear film stability. An important solvent in solvent based paint is white spirit, which contains $n$-decane as a major component. Therefore, it seems more likely to interpret the findings of eye irritation as due to exposure to organic solvents than to water based paints.

The painters also reported more problems with itching hands than did the controls. Skin irritation could be caused by the irritative effects of the sanding dust or when puttying and gluing glass fibre fabric. The water based paints, however, also comprise many additives with known irritative and allergic properties. To evaluate this about 200 painters have undergone a skin test with 46 different substances including components in water based paints. The preliminary results indicate a high prevalence of allergic reactions to preservatives, especially benzisothiazolinone. ${ }^{18}$

In conclusion our study indicates that the introduction of water based paints has improved the work environment for house painters. The actual brands of water based paints cause less malodour and airway irritation than the earlier solvent based paints. The general adverse health effects seem low. A few painters may, however, have dermal symptoms caused by some components in water based paints. From a practical point of view we suggest the use of airway protection devices when painting with wet room paints in confined spaces.

We acknowledge the help of Ingegerd Michel and Staffan Bohlin. This study was supported by a grant from the Swedish Work Environment Fund

1 Pirilä V. On occupational diseases of the skin among paint factory workers, painters, polishers and varmishers in Finland. A clinical and experimental study. Helsinki: 1947 (thesis).

2 Chapman E. Observations on the effect of paint on the kidneys with particular reference to the role of turpentine. Fournal of Industrial Hygiene and Toxicology 1941; 23:277-89.

3 International Agency for Research on Cancer. Monograph on the evaluation of carcinogenic risks to humans. Vol 47. Some organic solvents, resin monomers and related compounds, pigments and occupational exposures in pain manufacture and painting. Lyon:IARC; 1989:329-85.

4 World Health Organisation/Nordic Council Ministers Working Group. Chronic effects of organic solvents on the central nervous system and diagnostic criteria. central nervous system

5 Hansen MK, Larsen M, Cohr KH. Waterborne paints: a review of their chemistry and toxicology and the results of determinations during their use. Scand $f$ Work Environ Health 1987;13:473-85.

6 Van Faassen A, Borm PJA. Composition and health hazards of water-based construction paints: results from a survey in the Netherlands. Environ Health Perspect 1991 92:147-54.

7 Ulfvarson U, Alexanderson R, Dahlqvist M, Ekholm U, Bergström B, Scullman J. Temporary effects from exposure to water-borne paints. Scand f Work Environ Health 1992;18:376-87.

8 Askergren A, Beving $\mathrm{H}$, Hagman $\mathrm{M}$, Kristensson $\mathrm{J}$ Linroth $K$, Vesterberg $O$, Wennberg A. Biological effects of exposure to water-thinned and solvent-thinned paints in house painters. Arbete och Hälsa 1988;4:1-64 paints in house painters. Arbete och
(in Swedish with English summary).

9 Norbäck D, Rand G, Michel I, Amcoff S. The prevalence of symptoms associated with sick buildings and polluted industrial environments as compared to unexposed reference groups without expressed dissatisfaction Environment International 1989;15:85-94.

10 Michel I, Edling C, Lundin A, Hedenström $H$ Stålenheim S, Ekblad B. Pyrolysis products from polyethene-exposure levels and health effects. In: proceedings of 39th Nordic Meeting of Work Environment. Aulanko, Finland: Finnish Institute for Work Hygiene, 1990:19-20 (in Swedish).

11 Measurement of total dust and respirable dust. Stockholm: National Board of Occupational Safety and Health, 1979 (in Swedish). (Method No 1010.)

12 Levin J-O, Lindahl R, Andersson K. A passive sampler for formaldehyde in air using 2,4-dinitrophenylhydrazinecormaldehyde in air using 2,4-dinitrophenylhydrazineTechnology 1986;20:1273-6.

13 Andersson $\mathrm{K}$, Hallgren $\mathrm{C}$, Levin J-O, Nilsson C-A Chemosorption sampling and analysis of formaldehyde in air: influence on recovery during simultaneous sampling of formaldehyde, phenol, furfural, and furfury alcohol. Scand $\mathcal{F}$ Work Environ Health 1981;7:282-9.

14 Norbäck D, Michel I, Widström J. Indoor air quality and personal factors related to the sick building syndrome. Scand $\mathcal{F}$ Work Environ Health 1990;16:121-8.

15 Salzman BE. Lognormal model for health risk assessmen of fluctuating concentrations. Am Ind Hyg Assoc $¥ 1987$ 48:140-9.

16 Friman Hansen L, Damgård Nielsen G, Töttrup J, Abildgaard A, Dahl Jensen OF, Kragh Hansen M, Nielsen $O$. Biological determination of emission of 95-110.

17 Kjaergard S, Mölhave L, Pedersen OF. Human reactions to indoor air pollutants: n-decane. Environment to indoor air pollutants:

18 Fisher T, Rystedt I, Wieslander G. Allergic contact dermatitis from water based paints, glues and putty used by building painters. First Congress on the European Society of Contact dermatitis, 8-10 October. Brussels: 1992 (meeting abstract) 